\title{
Drug-Resistant Tuberculosis and Inhibition of Biosynthetic Enzymes for Polysaccharides in Mycobacterial Cell Wall
}

\author{
薬剤而性結核と結核菌細胞壁多糖生合成酵素阻害
}

Key Words: drug-resistant tuberculosis, polysaccharides in mycobacterial cell wall, inhibitions of biosynthetic enzymes

The control of pathogenic bacteria is essential to human survival. After the discovery of penicillin, it became to be possible to control previously serious pathogenic bacteria. However, some bacteria subsequently acquired penicillin resistance. The mechanisms of drug resistance are diverse as a result of both the variety and structure of drugs and their targets. In the case of penicillin, which inhibits the crosslinking of peptide strands in the cell wall peptide glycan, deactivation occurs after hydrolysis of a crucial $\beta$-lactam moiety by $\beta$-lactamase in resistant bacteria.

Mycobacterial tuberculosis is the causative agent of tuberculosis (TB) which is once again emerging in SouthEast Asia, African and Western Pacific regions, as well as in HIV-infected patients. Although TB is one of major public health concerns, more serious is the discovery of resistant TB, multidrug-resistant (MDR) TB and extensively drug-resistant (XDR) TB, as well as extremely drug-resistant (XXDR) TB, which is resistant to all first and second line drugs used to treat TB [Global Tuberculosis Control Reports, 2010, World Health Organization, Geneva, Switzerland].

The mycobacterial cell wall skeleton (CWS) contains unique polyfuranosides, such as galactan (inner) and arabinan (outer), connected to peptideglycan through linkers, which are not found in humans. Galactan is composed of $\beta$-Galf-(1 $\rightarrow 5)-\beta$-Gal $f$ repeating units linked by $\beta$ - $(1 \rightarrow 6)$-linkages. Arabinan was originally proposed to be a docosasaccharide, but was reclassified as a branched hentriacontasaccharide [Bhamidi, S. et al. (2008) J. Biol. Chem. 283, 12992-13000], which is a challenging synthetic target [Joe, M. et al. (2007) J. Am. Chem. Soc. 129, 9885-9901; Ishiwata, A. and Ito, Y. (2011) J. Am. Chem. Soc. 133, 2275-2291]. The biosynthetic enzymes for both galactan and arabinan may therefore act as alternative targets for anti-mycobacterial agents. Isoniazide (INH), an inhibitor of the biosynthesis of mycolic acid, which is the outermost shell component of CWS, has been already used for medical treatment, although INH-resistant strains have been recognized.

Studies have been conducted on inhibiting the biosynthesis of mycobacterial galactan by targeting either UDP-galactopyranose mutase (UGM) or galactofuranosyl transferase (GlfT), which are involved in the supply of glycosyl donor and elongation of sugar chains, respectively. Kiessling et al. reported that several lead compounds, including a thiazolidinone derivative, have been identified on high-throughput screening of a library of $c a, 16,000$ diverse small molecules with molecular weight of less than $500 \mathrm{Da}$ [Soltero-Higgin, M. et al. (2004) J. Am. Chem. Soc. 126, 126, (C2011 FCCA (Forum: Carbohydrates Coming of Age)
病原性細菌の制御は、我々人類の生存に不可欠である。抗 生物質ペニシリンが発見され、当時流行していた病原菌の制 御が可能となった。しかし細菌も、生存のために薬剤耐性を 獲得した。薬剤耐性のメカニズムは、薬剤の構造や標的が異 なるために、多様である。細菌細胞壁のペプチドグリカンの ペプチド鎖のクロスリンクを阻害するペニシリンに対する耐 性の場合、耐性細菌は $\beta$ - ラクタマーゼを保有し、 $\beta$ - ラク夕 么環を加水分解することでペニシリンを失活できる。

結核は、結核菌により引き起こされ、近年、東南アジア、 アフリカや西太平洋地域などで、またエイズ患者の間で感染 が広がり再び問題となっている。梁刻な問題は単なる結核菌 感染のみならず、薬剤耐性結核の出現にはじまり、さらには $\operatorname{MDR}$ (多剂耐性)-結核、MDR を超えた XDR (広範囲薬剤耐 性: 超多剂耐性) - 結核、そして全ての第一及び第二選択抗結 核菌薬が効かなくなってしまったXXDR (極度薬剤耐性)-結 核までの拡大である [Global Tuberculosis Control Reports, 2010, World Health Organization, Geneva, Switzerland]。

結核菌は細菌細胞壁成分として、人には見られない、特 徵的なフラノースからなるアラビナンとガラクタンを有して いる。その構造は、ペプチドグリカンょり、リンカーを介し て内側のガラクタン、続いて外側のアラビナンへとつながり 複雑である。ガラクタンは、 $\beta$-Galf-(1 $\rightarrow 5)$ - $\beta$ - Galf構造単位 が $\beta$ - (1 $\rightarrow 6)$ 結合でつながった繰り返し構造である。アラビ ナンは 22 糖とされていたが、 31 糖の分岐構造が最近提出され [Bhamidi, S. et al. (2008) J. Biol. Chem. 283, 12992-13000]、合成 化学者にとってチャレンジングな標的化合物でもある [Joe, M. et al. (2007) J. Am. Chem. Soc. 129, 9885-9901; Ishiwata, A. and Ito, Y. (2011) J. Am. Chem. Soc. 133, 2275-2291]。今までの抗結核菌 剤のターッゲットとは異なる、これらの生合成酵素群をター ゲットとした研究が進んでいる。なお、細胞壁複合糖質の最 外郭のミコール酸の生合成酵素阻害郕 (イソニアジド: INH) はすでに使用中だが、耐性が見られている。

まず、ガラクタンの生合成阻害剤は、糖供与体の供給に 関わるUDP-ガラクトースムターゼ (UGM)、糖鎖伸長に関わ るガラクトフラノース転移酵素 (GlfT) をターゲットにしたも のが研究されている。Kiessling らは、約 1 万 6 千個の分子量 500 以下の小分子化合物のライブラリーを UGM の阻害活性 についてスクリーニングし、チアゾリジノン構造を含むもの などいくつかのリード化合物を得た [Soltero-Higgin, M. et al. (2004) J. Am. Chem. Soc. 126, 126, 10532-10533]。しかし、それ 
10532-10533]; however, the thiazolidinone scaffold reacts reversibly with biological relevant thiols in solution and fails to block mycobacterial growth, and stable 2-amino-thiazoles with a similar structure as thiazolidinone derivatives showed comparable $K_{\mathrm{d}}$ values with improved growth inhibition activity [Dykhuizen, E. C. et al. (2008) J. Am. Chem. Soc. 130, 6706-6707]. Recently, Besra et al. described the synthesis of a uridine-linked transition state mimic designed as an inhibitor against GlfT2 [Trunkfield, A. E. et al. (2010) Bioorg. Med. Chem. 18, 2651-2663]. A carbagalactofuranose disaccharide was synthesized by Cumpstey et al., and was found to moderately inhibit the action of GlfT2 to the same degree as a uridine-linked transition state mimic [Frigell, J. et al. (2011) Eur. J. Org. Chem. 1367-1375.].

Development of inhibitors related to the biosynthesis of mycobacterial arabinan has been reported using approach to design analogues mimicking the decaprenyl phosphoryl- $\beta$ D-arabinofuranose (DPA) as the donor for arabonofuranosyl transferase (AraT) and decaprenyl phosphoryl- $\beta$-Dribofuranose (DPR) 2'-epimerase (DrpE1 together with DrpE2), which supplies DPA for AraT. Fairbanks et al. reported the synthesis of $\beta$-D-arabonofuranosyl triazole and sulfone derivatives through click reaction of glycosyl azide [Wilkinson, B. L. et al. (2008) Bioorg. Med. Chem. Lett. 18, 6265-6267.] and oxidation of thioglycoside [Ayers, B. et al. (2009) Carbohydr. Res. 344, 739-746], respectively. Anti-mycobacterial activity of these compounds was found to be low to moderate, and even the most potent compound was less active than INH. On the other hand, Cole et al. developed benzothiadinone (BTZ) derivatives as potential anti-mycobacterial agents [Makarov, V. et al. (2009) Science, 324, 801-804.]. Crucially, BTZ displayed similar activity against all clinical isolates of $M$. tuberculosis that were tested, including MDR and XDR strains. These results suggest that target of BTZ derivatives is a previously unknown biological function, and BTZ derivatives were found to inhibit DrpE1 or DrpE2. DPR is converted to DPA in two steps through oxidation by DrpE1 followed by reduction by DrpE2. BTZ derivatives irreversibly bind with DrpE1, inhibit the oxidation at 2' position of ribofuranose, block supply of DPA, and exhibit high anti-mycobacterial activity [Trefzer, C. et al. (2010) J. Am. Chem. Soc. 132, 13663-13665].

The control of pathogenic bacteria is essential to human survival. Although several promising candidates have been described herein, the cycle of control of pathogenic bacteria followed by development of resistance is likely to be repeated until new drug development ceases. Continuous investigation of novel targets for new drugs is therefore required.

Reported by Akihiro Ishiwata RIKEN · Advanced Science Institute

Hirosawa, Wako 351-0198, Japan

E-mail: aishiwa@riken.jp

FAX:81-(0)48-462-4680
らは生体内のチオール溶液中では不安定で、結核菌の生育を 止めることができなかった。そこで、チアゾリジノン構造に 類似し、かつ安定な2-アミノチアゾール誘導体を合成し阻害 活性をスクリーニングしたところ、それは2-アミノチアゾー ル誘導体と同程度の $\mathrm{Kd}$ 值を有し、かつ生育阻害も併せ持つ ことがわかった [Dykhuizen, E. C. et al. (2008) J. Am. Chem. Soc. 130, 6706-6707]。一方 Besra らは、最近、GlfT2による転移反 応の遷移状態を模倣したウリジン結合型阻害剤の合成を行っ ている [Trunkfield, A. E. et al. (2010) Bioorg. Med. Chem. 18, 2651 -2663]。また、Cumpstey らは、カルバガラクトフラノース 2 糖を合成し、ウリジン結合型阻害剂と同程度の活性を持つ ことが示された [Frigell, J. et al. (2011) Eur. J. Org. Chem. 13671375]。

次に、アラビナンの生合成に関する阻害剂開発研究は、 アラビノフラノース転移酵素 (AraT) の糖供与体 (デカプレ ニルホスホリル - $\beta$-D- アラビノフラノース $\mathrm{DPA})$ のアナロ グによるものと、DPA の供給に関わるデカプレニルホスホ リル - $\beta$-D-リボフラノース (DPR) 2' - エピメラーゼ (DrpE1 -DrpE2) をターゲットにしたものが最近報告されている。 Fairbanks らは、AraTの糖供与体 DPA アナログとして、ク リック反応にてグリコシルアジドより $\beta$-D - アラビノフラノ シルトリアゾール誘導体 [Wilkinson, B. L. et al. (2008) Bioorg. Med.Chem. Lett. 18, 6265-6267] を合成し、さらにチオグリコシ ドの酸化反応により $\beta$-D- アラビノフラノシルスルホン誘導体 [Ayers, B. et al. (2009) Carbohydr. Res. 344, 739-746] を合成した。 しかし、抗菌活性は中程度以下で、最も活性なものでも INH より低く、期待した抗菌活性を示さなかった。一方、Cole らは、 抗結核菌薬の候補として、ベンゾチアジノン (BTZ) 誘導体を 開発した [Makarov, V. et al. (2009) Science, 324, 801-804]。BTZ は、MDR やXDR を含む全ての結核菌に対して同程度の感受 性を示す。BTZのターゲットは既存のターゲットとは異なる ことが示唆されたが、DrpE1-DrpE2 の阻害剤であることが見 いだされた。DPR から DPA へは DrpE1 による酸化と DrpE2 による還元の 2 段階の変換を経る。BTZ 誘導体は DrpE1 と非 可逆的に結合し、1 段階目の酸化を阻害する [Trefzer, C. et al. (2010) J. Am. Chem. Soc. 132, 13663-13665] ことで、DPA 供給 を止め、高い抗結核菌活性を示す。

病原性細菌の制御は、我々人類の生存に不可欠である。 いくつか候補を述べたが、また病原性細菌の制御と耐性獲得 は新薬のリリースが途絶えるまで繰り返されるかもしれない。 引き続き新薬開発のための新しいターゲットの探索研究が必 須であろう。

石渡 明弘

独立行政法人理化学研究所 - 基幹研究所 